\title{
Research on University Network Teaching Platform (Blackboard) in Teaching Management
}

\author{
Zhao Xia Gou \\ Teacher's College, Beihua University, Jilin, China
}

\begin{abstract}
With rapid development of online education; teaching platform based on the network, as a new instructional mode has become a hot topic in online teaching. In this paper, the he teaching situation and existing problems on online was analyzed by comparing the difference between network teaching platform and traditional classroom teaching. Then the strategies of network teaching management and the case, which is focusing on the characteristics of Blackboard with the application of network teaching management was presents.
\end{abstract}

\section{General instruction}

The 21 st century is dependent on the network in the digital environment and the survival of the community. Network, as a way of life, are quietly changing us. Its powerful transfer, learning and entertainment functions are people relish. Will partially replace the network-based education and supplement traditional forms of secondary education have become a new growth point of education in the 21 st century. With the breakthrough development of information technology, network teaching platform based education as an important way of education, popularization of education, education and lifelong learning of social provides a good technical platform, the extension of the development of online education and improve the quality of teaching provided strong support.

With the development of network technology, the traditional teaching methods can not meet the people's needs, online teaching as a new form of education and means to break the time and space limitations of traditional teaching. For some reason, online distance education in our country started late, but developed rapidly. Our colleges and universities since 1996, made use of the advantages of resources Universities conduct envisaged Teaching. The past 10 years, with the continuous change, network teaching digitization, sharing, timeliness, interactivity, individualized teaching, abundant teaching resources, etc. has become increasingly prominent, online teaching has become one of the most important teaching mode.

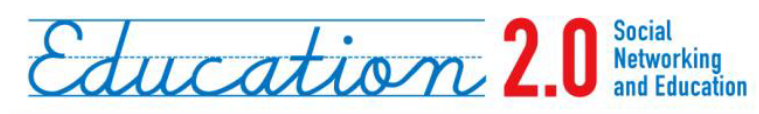

U.S. Students \& social networking:

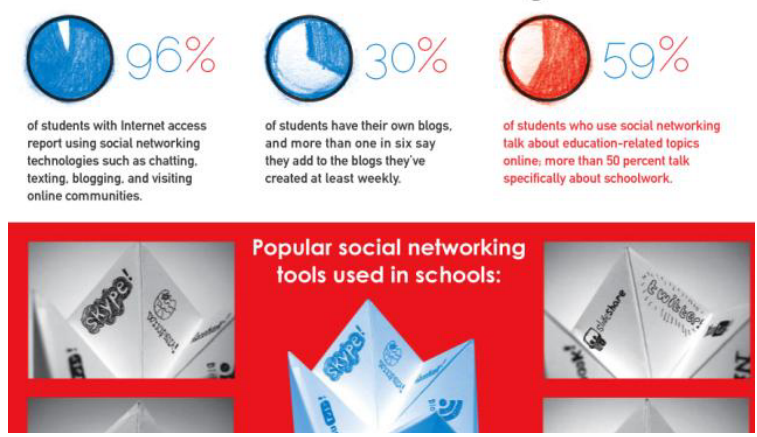

Figure 1. Education proportion in U.S

\section{Major feature online teaching}

First, focus on two-way exchange of teaching methods. The first major feature online teaching is a focus on twoway exchange of teaching methods. In the network of teaching methods, students can discover the one hand, in the learning process and the lack of progress, take the initiative to arrange referrals to adjust their learning to teachers to adapt teaching requirements; the other hand, teachers can understand students' learning processes through the network, The arrangements for the actual situation of teaching students to adjust according to the student. Through the exchange of teachers and students are in a timely manner, to ensure the quality and efficiency of student learning. The most obvious manifestation is the anti- "SARS" the very moment, in order to avoid its spread person-oriented or crossinfection, many schools have been closed or holiday, let students learn at school or at home on their own. If 
conditions allow it (student dormitories or at home with computers with Internet access, etc.), the school can arrange for teachers and students learning through the network.

Second, students are required to learn a higher consciousness, collaboration. Another feature of the network is not only teaching students to learn a higher consciousness, also requires students to have a strong collaboration in learning. In the network teaching, students are not only to communicate with teachers, but also to communicate with other students. Students and teachers through a network of direct dialogue in order to get to the course to help students at the same time you can also get inspired by each other through the network to discuss the discussion with other students on the same course. Teaching in this communication network is regular, is necessary, which is advantageous in improving the quality and efficiency of student learning.

Third, the traditional "teacher-centred" is to the "studentcentred." With the changes in the teaching and learning environment, online teaching has changed the traditional teaching concept "teacher-centred" and establish a "student-centred" new teaching concept, teachers and students in teaching roles change, students master learning The initiative, in earth moving, active learning the position, and then play the mentor teacher, mentor role. Teaching performance concept "student-centred" are: in the teaching process, students are around this centre, students enjoy the right to choose a course of clay, teachers, learning progress, learning time and so on. For example, students can query the network, want to choose their own course of study; call white already required in the teaching learning materials database: When you encounter a problem, you can request guidance or assistance to teachers through the network; also can network with other learners to discuss issues, exchange ideas; the problem can also participate in various discussions, etc. online. In short, the whole teaching activities are around to help students learn the subject, study the initiative entirely to the students, of course, which requires students to have a high learning consciousness, consciously use the network with the adjustment of learning.

Fourth, the teaching unity is personalized and collaborative learning models. Network teaching height reflects the individualized instruction and collaborative learning mode unity. Traditional classroom teaching for different students using the same textbooks, teaching methods, the "injection" type of knowledge indoctrination, this teaching is not conducive to play the potential of student's personality, is not conducive to the cultivation of innovative talents. Interactive learning, very suitable for student's individual learning, that is, from students to choose courses, discipline, progress, learning, etc., truly individualized, each student receives a "tailored" type of teaching, student's individual potential into full play.

Collaborative learning theory can be said online teaching constructivist learning theory. Constructivism holds that learning is learner with others, learners and the external environment; learners interact with the outside world produced. The theory emphasizes learner-centred, on the one hand requires the learner to the subject of information processing, knowledge of the significance of the transition from the active builders instil objects passive recipients of external stimuli and knowledge; it also requires teachers from the simple knowledge imparting, instilling active learners who construct meaning helper and facilitator transformation. Therefore, teaching students in both networks with other learners of ideas, but also with teachers learn to solve problems on a network.

\section{The advantages of network teaching platform Teaching}

On the Internet organized by hyperlink construct knowledge, vast information base to become the world's largest information resources to enable learners to share teaching resources different countries or log on to another educational network covered the required information, enrich the teaching content, broaden their horizons learners. This is not only conducive to the development of associative thinking and establishes links between old and new knowledge, but also for the formation and development of students' cognitive structure, namely the promotion of students to construct knowledge about the current is very advantageous.

With modern society people live, work accelerated pace of learning time for service personnel only relatively small, but also more and more fragmented, difficult for them out of a long and stable time to continue learning. Openness of the Internet so that people realize the sharing of information resources, from the traditional teaching strict requirements of time and place for learning, learners anytime, anywhere, with remote teaching system, VCD VOD system, according to their own needs flexible learning time arrangements and learning progress also can rely on teaching information retrieval system or public multimedia communication network, remote share educational resources and teacher guidance. And the network so that education has undergone profound changes, the whole process can be achieved in the online education, including Registration, study and practice, exams and scores, diploma and degree, etc., through the online school, so that more people round the university dream, rather than desperately to get into the college entrance examination this difficult path. This will not only help the implementation of quality education, but also to cultivate more knowledge economy requires adaptation of new talent.

Quality and quantity of traditional teaching is largely restricted level of teachers and school facilities and other conditions, online education is different, not only the number of students in the virtual classroom is no longer restricted, and can be combined in different school teachers taught the course content with graphics, sound, video and other multimedia forms, has greatly improved the school conditions and the environment. From the Java language online courses, practice basic computer literacy 
courses teaching website, the network teaching methods in solving the popular courses of teachers, classrooms and other restrictions can play a significant role, it is worth further exploration and push) 'one. Also, the job and the exam is very heavy teaching, but the traditional way of work and exam burden on teachers too, so that teachers can not effectively use these two teaching methods. If you use the Internet will be able to solve this problem, the teacher will be able to get a lot of students learning first-hand materials, which have targeted for teachers to guide students to learn a lot of good.

Only network courseware platform online is teaching to be able to really only across time, space constraints, the breakthrough 40 minutes of constraint, the application of courseware from curricular and extra-curricular extension to allow our teachers to re-understanding as a whole, on the Course integration. Only with the network teaching platform, it may not need to produce their own teachers difficult courseware, interactive dynamic web pages written in script, we only need a simple text editor similar to Word can have fully functional network courseware, leaving out more time to focus on teaching itself. It can be said that only with the support of network teaching platform, the curriculum integration will truly become "open, resource-centred curriculum integration" powerful interactive information technology to be available to better reflect the traditional classroom teaching You can gradually expand to extracurricular theme explored in order to achieve effective, real inquiry.

\section{Comparative analysis of network teaching platform ordinary classroom}

Manage network teaching platform Teaching compared with ordinary classroom teaching management, in the end what is the difference? Recognize this, is the basis for teaching management network teaching platform, which requires the network teaching platform Teaching Management and ordinary classroom teaching management analysis Compare. The so-called ordinary classroom teaching management is in school, college or university campus in the general level of non-networked classroom teaching management, in fact, the management of network teaching platform Teaching ordinary classroom management and teaching there in some respects great similarities, the two are not completely separate, but after teaching online teaching platform is a new educational model, there is a big difference compared to the teaching environment and general education, therefore, teaching both conducted management inevitably vary.

Management body: Bodies of teaching management means are management science knowledge and skills have appropriate authority, engaged in teaching and management activities. In teaching management, each person can be both management body, it could be managed object, in different teaching administration, or at different times in the same teaching administration, people often play different roles, changing his identity, performance for the conversion of teaching management subjects and objects. Network teaching platform is teaching management, the body managing teachers, curriculum content administrators, and assistants and student performance evaluation. Work organization and daily management of the teacher is not only responsible for learning this course, there are FAQs and classroom teachers to provide students with the case administrator course content, even in the page, CAI courseware preparation of technical personnel, they all belong to the network teaching subjects teaching management platform. Subject ordinary classroom teaching management is relatively simple, the manager basically limited to teach instructors, teachers often several roles, both in charge of the course, marking students' work, is also responsible for the student's Tutor and even computer-aided instruction software design.

Management Object: The object of teaching management means for teaching management subjects of understanding and transforming objects with teaching management associated soil. About managing objects, including what elements exist in management science in different views: Some people, financial, and material, "said the three factors"; someone, financial, material, time and information, "said the five-factor", someone, financial, material, time Information, ten gas, the method "a seven said," and so on. On the management of network teaching platform in terms of teaching, this paper argues people, goods, information the three factors are essential elements of teaching management object. People mainly refer to the object of teaching, knowledge of the recipient, the following class focuses on lobbyists and informational material object.

(1) Material class object. Substance class object network teaching platform teaching management are: the Internet, video conferencing systems, virtual laboratories, virtual classroom, e-learning studio and so on. To manage these products, to ensure the normal operation of teaching work, which is difficult to manage quite large? The substance class object ordinary classroom teaching soils have classroom management and so on, of course, including the management of said network management platform for teaching in the teaching material class objects, but they are not yet dominant in ordinary teaching.

(2) Information objects class. In the network teaching platform in teaching, teaching is mainly carried out through the network; therefore, the information object class teaching management is primarily a network of educational information resources. As the network environment, complex and diverse sources of information, generous, produce and disseminate information without screening and validation, information object class classroom teaching soils common management if the print media, of course, also includes part of non-print media, its management the difficulty is clearly not the former.

Management Model: clues from history teaching management development, the teaching management mode can be divided into empirical management, administration management mode and science-based 
management are three basic types, including sciencebased teaching management mode can be divided into deterministic, random, fuzzy type, system management mode. These management modes used in practice are not mutually exclusive, but mutually intersect, complement each other, but in a different mode of teaching, managers will mainly using one or several teaching management mode for teaching management.

This paper argues that the teaching management network teaching platform, should mainly stochastic and fuzzy type teaching management mode of teaching management. The so-called random type of teaching management pattern is to randomness science as guidance, acknowledge the complexity of the object, chance, mutation, using statistical regularity and randomness of mathematical models for analysis, forecasting, and then plan to implement a science teaching management. In teaching management network teaching platform, there are a lot of random phenomena, such as, teaching content, teaching methods with the rapid development of modern science and technology exhibit uncertainty. Also, the teaching process is affected network operation status, computer performance and other factors; the possibility of teaching interrupt is random. The so-called fuzzy type of teaching management is fuzzy thinking and fuzzy theory, complexity sure the object, fuzziness and fuzzy theory and fuzzy mathematical models for analysis, decisionmaking and evaluation, and then the implementation of a new management Science-based teaching management model. This model is concerned that the daily work of the Organization of instability and complexity. Furthermore, in the era of rapid social change, schools may be difficult to interpret a variety of information and demand signals from the external environment, it is difficult to deal with the many contradictions arising there from, this exotic uncertain information, and will certainly increase fuzziness decision-making process within the school, at the same time, the rapid development of network technology, knowledge updated accelerating teaching management have increased randomness and fuzziness.

\section{Conclusion}

In common classroom management, the main use of administrative type and determine the type of teaching management mode of teaching management. Teaching administrative management emphasizes the authority of administrative rule-based and regulatory organizations at all levels, the use of administrative measures and administrative means mandatory, in accordance with procedures established norms, promoting and teaching management. This teaching management model reflects the organization leadership authority. Determine the type of teaching management mode, making full use of past experience, to develop a series of plans on the basis of past experience, organization, rules and regulations, in accordance with a defined path, methodically, step by step forward.
Management tools: network teaching platform management tools in teaching computer and network technology-based, computer-based form of teaching management information system, through high-speed computing and mass storage functions of the computer, teaching management information collection, transmission, storage and processing, timely and accurately provide useful information to management, to support managers to achieve the training objectives and scientific decision-making and effective control. Education Management Information System is suitable for almost the entire range of teaching management, which includes: the teaching plan management, teaching management, teaching quality management, teacher management. The general education teaching management currently in use is still largely manual management methods, at least for now is still in the stage of development of the computer network direction.

From the viewpoint of the system point of view, any organization is a system; it exists in a more human system. The larger system is the existence and development of the environment, the organization is always inseparable from the environment. Management of the environment can be divided into two human beings: one is the general environment, including natural and social environment; the other is a special environment, mainly refers to the environment within the organization, also known as the working environment, which includes the physical environment, spiritual environment and information environment three aspects. The following face on special education and general education environment network teaching management to do a comparison.

\section{References}

1. Karl Engkvist. Digital Learning Application and Development of the global user experience Blackboard articles .Chief Operating Officer

2. CERNET-Blackboard Technology Ltd., 230 (2005)

3. Like Dong sharing online resources to build Internet interactive learning environment Guangdong: South China Normal Science, 11 (2005)

4. John Fritz Bob Armstrong. Using Blackboard Communities for Student Government Elections and Orientation.45 (2005)

5. Tang Fuyuan, Xu Lihua Based on Blackboard Teaching Information Technology Discussion Education information, 94 (2005)

6. Han Joan personal knowledge management theory and research. DETAILED DESCRIPTION Jiangsu Nanjing Normal University, 25 (2007)

7. Zhenghan Wen. Cooperative learning classroom management strategies. Wuhan University of Science and Technology, 12 (2006)

8. Yao Castle. Xie broad-based network platform exchange of teachers and students. Zhengzhou Management + Department of University of Economics, 9 (2006) 
9. Zhujie Lan research and model of college classroom knowledge management system to build. China Distance Education, 61 (2006) 